\title{
"Transformation of human capital strategies in the tourism industry under the influence of Economy 4.0"
}

\begin{tabular}{|c|c|}
\hline \multirow{5}{*}{ AUTHORS } & Olena Stryzhak (iD) \\
\hline & Olena Akhmedova (iD) \\
\hline & Nelli Leonenko (iD) \\
\hline & Inna Lopatchenko (i) \\
\hline & Nataliia Hrabar (D) \\
\hline ARTICLE INFO & $\begin{array}{l}\text { Olena Stryzhak, Olena Akhmedova, Nelli Leonenko, Inna Lopatchenko and } \\
\text { Nataliia Hrabar (2021). Transformation of human capital strategies in the tourism } \\
\text { industry under the influence of Economy 4.0. Problems and Perspectives in } \\
\text { Management, 19(2), 145-156. doi:10.21511/ppm.19(2).2021.12 }\end{array}$ \\
\hline DOI & http://dx.doi.org/10.21511/ppm.19(2).2021.12 \\
\hline RELEASED ON & Wednesday, 26 May 2021 \\
\hline RECEIVED ON & Sunday, 28 February 2021 \\
\hline \multirow[t]{2}{*}{ ACCEPTED ON } & Tuesday, 18 May 2021 \\
\hline & $((c))_{E Y}$ \\
\hline LICENSE & $\begin{array}{l}\text { This work is licensed under a Creative Commons Attribution } 4.0 \text { International } \\
\text { License }\end{array}$ \\
\hline JOURNAL & "Problems and Perspectives in Management" \\
\hline ISSN PRINT & $1727-7051$ \\
\hline ISSN ONLINE & $1810-5467$ \\
\hline PUBLISHER & LLC "Consulting Publishing Company "Business Perspectives" \\
\hline FOUNDER & LLC "Consulting Publishing Company "Business Perspectives" \\
\hline
\end{tabular}

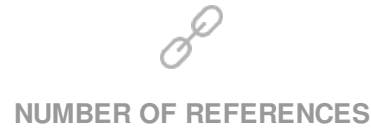

30

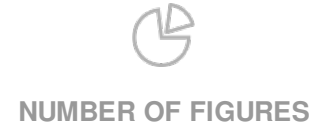

3
NUMBER OF TABLES

8

(C) The author(s) 2021. This publication is an open access article. 


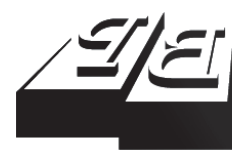

BUSINESS PERSPECTIVES

()

LLC "CPC "Business Perspectives" Hryhorii Skovoroda lane, 10, Sumy, 40022, Ukraine www.businessperspectives.org

Received on: $28^{\text {th }}$ of February, 2021

Accepted on: $18^{\text {th }}$ of May, 2021

Published on: $26^{\text {th }}$ of May, 2021

() Olena Stryzhak, Olena Akhmedova, Nelli Leonenko, Inna Lopatchenko,

Nataliia Hrabar, 2021

Olena Stryzhak, Ph.D. in Economics, Associate Professor, Tourism Department, Simon Kuznets Kharkiv National University of Economics, Ukraine. (Corresponding author)

Olena Akhmedova, Ph.D. in Public Administration, Associate Professor Tourism Department, Simon Kuznets Kharkiv National University of Economics, Ukraine.

Nelli Leonenko, Ph.D in Economics, Head of the Department of Management, National University of Civil Defence of Ukraine, Ukraine.

Inna Lopatchenko, Ph.D. in Public Administration, Lecturer, Departmen of Public Administration in the Field of Civil Defence, National University of Civil Defence of Ukraine, Ukraine.

Nataliia Hrabar, Ph.D. in Public Administration, Leading Research Worker, Science Division in Problem of Managing in Civil Defence Area, Training Research and Production Center, National University of Civil Defence of Ukraine, Ukraine.

This is an Open Access article distributed under the terms of the Creative Commons Attribution 4.0 International license, which permits unrestricted re-use, distribution, and reproduction in any medium, provided the original work is properly cited.

Conflict of interest statement: Author(s) reported no conflict of interest

Olena Stryzhak (Ukraine), Olena Akhmedova (Ukraine), Nelli Leonenko (Ukraine), Inna Lopatchenko (Ukraine), Nataliia Hrabar (Ukraine)

TRANSFORMATION

OF HUMAN CAPITAL STRATEGIES IN THE TOURISM INDUSTRY UNDER THE INFLUENCE OF ECONOMY 4.0

\begin{abstract}
The digital transformation of society affects socio-economic relations in all spheres of life; however, the degree of this influence differs depending on countries and regions. Various industries and sectors of the economy are also affected by digitalization to one degree or another.

In this context, the purpose of the paper is to determine the dependence of human capital in the tourism industry on the digitalization level of the economy.

The following methods were used: data standardization, cluster analysis, analysis of variance, $\mathrm{K}$ means, and SWOT analysis.

The panel sample includes indicators from 61 countries for 2018. The analysis revealed distinctive features that allowed allocating the countries into clusters. Cluster 1 (14 cases): countries with average Human Capital Index (HCI) and World Digital Competitiveness (WDC) values, depending on tourism. Cluster 2 (13 cases): countries with slightly above average HCI and WDC values that are less dependent on tourism. Cluster 3 (15 cases): countries with HCI and WDC values below average, not particularly dependent on tourism. Cluster 4 ( 1 case): outliers. Cluster 5 (18 cases): countries with above average HCI and WDC that are tourism dependent. The calculation results made it possible to identify the cluster principles. The use of the identified distinctive features in the SWOT analysis allows formulating the key elements of human capital strategies in the tourism sector for each group of countries.
\end{abstract}

\section{Keywords}

JEL Classification

\section{INTRODUCTION}

The modern digital transformation of society, the result of which is the formation of Economy 4.0, significantly affects socio-economic relations in all spheres of life. The development of the digital economy opens up new opportunities for economic entities, which is expressed in the rapid exchange of information, the formation of networks, increased productivity on the one hand, and increased risks associated with security and dependence on the systems for exchanging, distributing and storing information on the other. In addition, digitalization is widening the gap between countries and their economic agents conditioned by the possibilities of the digital technology introduction and use.

Changes in technologies cause corresponding structural shifts in employment and in the labor market - some professions turn out to be unclaimed, and the demand for these professions is gradually decreas- 
ing, while others are becoming an objective necessity of the new digital economy and provide their owners with the competitive advantages and prospects for high income. Economy 4.0 activates the formation of the personnel's new competencies, the development of creative human capital, and the introduction of lifelong education systems.

Digitalization has affected all spheres and industries, and tourism is no exception. The widespread introduction of modern booking and reservation technologies, the development of logistics and search engines, on the one hand, make travel more accessible, but on the other hand, they complicate the process of developing, selecting and implementing a tour. Therefore, for travel agencies, more than ever, the issues of compliance of the employees' competencies with the increasing digitalization of tourism are extremely relevant. In this context, it is necessary to solve the problem of aligning the human capital strategies of travel agencies with the realities of the formation of Economy 4.0.

\section{LITERATURE REVIEW}

Analysis of the literature on the subject of the paper shows that only certain directions in its scope have been researched, which indicates the urgency of the issue and the need for further study. Thus, researchers have recurrently emphasized the relationship between firm performance and human capital productivity, dependence of economic growth on human capital development (Pelinescu, 2015). Rahim et al. (2017) measured the performance of human capital (in the Malaysian technology industry) and provided some empirical data useful for business and state regulatory bodies. Tran and Vo (2020) go even further and analyze firm productivity across economic sectors in Vietnam to confirm that human capital efficiency positively influences these sectors and affects firm financial gains. At the same time, the managerial mechanism of shaping the human capital formation and the effectiveness of investment into this asset has to be constantly monitored and evaluated by a company's management (Gadzhiev et al., 2020). In general, a country's sustainable growth directly correlates with the human capital quality. Simultaneously, the quality of the country's institutional environment directly influences the level of human development (Stryzhak, 2019).

The advances in the technology, the processes of digitalization considerably influence the employment and occupation spheres in both positive and negative ways. Hence, scientists concern the human capital deterioration due to its decreasing creativity, direct dependence of unemployment on production automation, complication of the programs performed by people. Nonetheless, the
4.0 revolution leads to the transformation in the allocation of working tasks, changes in the role distribution between humans and artificial intelligence, innovations in the fields of marketing, customer care and competition (Sima et al., 2020; Ślusarczyk, 2018). Researchers focus on the competences, skills and abilities of the labor force in the conditions of Industry 4.0 and the challenges it presents for business, private sector and scientific research (Frey \& Osborne, 2017; Flores et al., 2020; Stachová et al., 2019). In this respect, the development and education of the younger generation comes to the fore, becoming one of the aspects of the company's social responsibility (Scavarda et al., 2019). The talent nurturing, management and retention is also of vital importance and has to be studied from both theoretical and practical perspectives (Whysall et al., 2019).

Tourism sector is no exception, since until lately, it was considered as one of the driving forces of the world economy and being a service sector, it demands considerable investments in the development of human capital. Many destinations of the approximately equal level consider human resources as the basic factor of differentiation and main competitive advantage because employees directly work with clients, implicitly defining the quality of services and providing consumer satisfaction (Lut \& Vlad, 2017). The lack of professionalism in private and public sectors of tourism lead to shortages in sales, which highlights the correlation between the tourism industry progress and the quality of its human capital base (the case of Nigeria, Esu, 2012). Therefore, various trainings and courses for the tourism sector personnel are vital to enhance the destination's trademark im- 
age, sustainable development and quality services (Bourouaha et al., 2017), which considerably depend on the investments in the tourism industry as a whole and human capital in particular (Kozmenko et al., 2015). Transition to the knowledge-based economy requires tourism employees to update qualification, receive new skills and practice lifelong learning. In Portugal (Costa et al., 2019), this resulted in a new project connecting educational institutions and tourism companies to improve employees' hard and soft skills and thus supporting Portugal's image as one of the best tourism directions.

The development of the employees' human and intellectual capital is pivotal for the tourism industry. Many organizations in this sphere lack structured human resource management practices. Understanding how these practices improve employee productivity and company performance can stimulate human capital development (Alamu, 2016). Besides, it is important to measure the level of travel agents' satisfaction with work and the level of stress, which makes people leave profession in general, and salaries in particular and how much it depends on the level of education and qualifications in tourism, the stimulus to acquire new experiences (Ribeiro et al., 2020). In this context, it is necessary to mention that the level of happiness and life satisfaction directly depend on the level of education (Stryzhak, 2020) and leads to higher incomes, more freedom and longer lives.

Digital economy makes companies rethink the way they operate. In tourism, for instance, it is a completely new way of gathering statistical information and data, for developing countries, it is a new opportunity to present and promote destinations, thus, increasing sales and incomes (Hojeghan \& Esfangareh, 2011).

Contemporary studies concerning human capital indicate the role of digitalization and digital infrastructure for the staff's advancement at small enterprises and, especially, in remote districts. In the framework of the digital economy, human capital formation is also of great interest today (Zaborovskaia et al., 2020). Demands for the improvement of the population's digital skills and competences are increasing, especially in the regions, and this shifts the focus of educa- tion to the widening of the personal competencies (Gerasimova et al., 2020). At the same time, there is strong resistance to the use of digital technologies not only by human resources but also by the end users, which can result in the failure of many projects. Thus, management focused on personnel and their role in a company structure, organizational self-awareness, logical job description leads to better adaptation to all new digital technology implementations (Saraiva, 2018). Digital technologies reshape strategies of the personnel development, talent management and retention. Consequently, there should be visible results for the public sector or a private enterprise concerning performance, service quality, product range and assortment. The important question is how to monitor and estimate the correlation between digital revolution, human resource management and performance (Betchoo, 2016). For this, in terms of the digital transformation, the human resource reform has to be introduced, including all aspects of working with personnel - from onboarding to salary and performance management to company leaving (Lei \& Jing, 2016).

The term "Industry 4.0" appeared in Germany in 2011, and initially denoted the processes of radical transformation of the global value chains; at the present stage of the development of economic relations, the notion manifests an integral philosophy of doing business, the basis of which is the use of modern digital and information technologies. Although the changes caused by these technologies relate, first of all, to the processes of generation, creation, storage and use of information, ultimately, they affected all socio-economic activities.

Economy 4.0 is a public relations system based on digital communication and information technologies, whereby customized products and services are created using blockchain technology. The widespread use of information technologies allows a consumer to participate in the process of a product creation. At the same time, all production processes provide for the end-to-end digitalization of both the means of production and the subjects of labor.

The G20 Digital Economy Development and Cooperation Initiative proclaims that the digital economy is a wide range of economic doings, which 
includes the use of digitized knowledge and information as an essential component of production, the implementation of the contemporary information networks as a vital area of activity. Besides, the well-thought-out application of information and communication technologies (ICT) as a major force of productivity progress and structural optimization of the economy (G20) is presented. Tay et al. (2018) described Industry 4.0 as a global phenomenon influencing all directions of the company's work by means of digitalization and automation, and also by the production operations.

Wyrwicka and Mrugalska have demonstrated that Industry 4.0 provides a competitive advantage for any industry. Namely, contemporary mechanisms, devices and machinery can be applied for planning, forecasting, regulating, and controlling business processes because they are manufactured using modern software and network sensors (Wyrwicka \& Mrugalska, 2017).

In the context of rapid digitalization, human capital is becoming one of the locomotives of the economic growth, since the personnel's ability to learn and constantly update knowledge becomes a key factor in achieving competitive advantage. Information technologies permeate all areas of the society's activity, transform industrial relations, assigning a crucial role to the ability to network interaction, the ability to receive, interpret and use information to achieve goals and objectives.

One of the ultimate advantages of the digitalization expansion is the possibilities of the personnel attraction, training and development, increasing labor productivity using digital technologies, and replacing a number of routine operations through automation. Contemporaneously, the prevalent introduction of modern digital technologies leads to the fundamental changes in the requirements of the personnel's qualifications, worker displacement from a number of production processes. The ongoing processes are twofold; on the one hand, the quality of working activity is improving, it becomes more creative and diverse, and on the other hand, modern technological processes require highly qualified employees in the field of digital and information technologies, and, at the same time, lead to a decrease in the labor market employment.
The paper is aimed at determining the degree of influence of the economy digitalization level on human capital in the tourism industry.

The research hypothesis is as follows: Digital technologies in the context of society's transition to Economy 4.0 have a differentiated impact on various areas of economic activity and countries. In this context, the impact of Economy 4.0 will vary from country to country, depending on the level of human capital development and the degree of digitalization of the country.

\section{METHODS AND DATA}

The following methods were used in the paper: data standardization - to bring data to comparable values, cluster analysis - to distribute countries into groups (complete link method was taken as a rule, and Euclidean distance was taken as a measure of proximity), analysis of variance - to describe the clusters, $\mathrm{K}$ means- to determine mean and confidence intervals for variables in each cluster, and SWOT analysis of human resources - to develop human capital strategies in tourism enterprises.

Tourism is one of the sectors that have already felt the impact of global informatization. The development of booking, reserving, issuing insurance technologies, a widespread use of mobile applications for the creation of tourist routes, tour-guiding services, searching for tours, etc. helps people to travel independently, without travel agencies' help. In this situation, retaining regular customers and attracting new consumers, as well as searching for new channels of the customer service and developing a unique tourist product are an important task for the tourism industry.

Tourism company personnel plays various roles such as: welcomes consumers representing the company; acts for the company image, being completely responsible for the client's first impressions and company quality standards; becomes an essential element of differentiation and competitive ad-vantage; acts as a vital part of the product proposition, which happens in front of consumers and with their participation, accounting for the desired service quality, and attempting to satisfy the consumers' most exquisite and special choices. 
Therefore, faced with the increasing digitalization, the tourism sector needs to update its human capital management strategies focused on developing ICT competencies.

From this point of view, the design of human capital strategies in tourism should address the peculiarities of the human capital quality, the degree of digitalization, and the level of tourism development in the country. International tourism receipts (current USD) (ITR) display the level of tourism development. Human Capital Index characterizes the human capital quality. The World Digital Competitiveness ranking represents the level of digitalization.

The international inbound visitors' spending is known as international tourism receipts, which also comprises compensations to national carriers for international transport. Any other expenditures on obtaining the products or services in the country of destination are included into these receipts. The receipts for goods or serviced provided to tourists may also be added to international tourism receipts unless they undergo a different classification.
Human Capital Index (HCI) is an international standard that defines key characteristics of human capital across the world countries. The HCI demonstrates how the contemporary level of health and education forms the structure of the working force of the next generation. It also indicates the volume of a country's losses through insufficient care for citizens' health and education levels. The final indicator varies from zero to one and defines the productivity of a perspective worker compared to the ideal health and complete education.

The IMD World Digital Competitiveness (WDC) ranking studies and ranks the level to which countries follow and research digital technologies, which result in changes in the governmental approaches, variants of business organizations and society in general. The methodology of the WDC ranking specifies digital competitiveness into the following main indicators: Knowledge, Technology, and Future readiness. Digital competitiveness is understood as the ability of an economy to embrace and study digital technologies in all spheres of the society's economic and social life. This arrangement adds to the overall ranking by

Tree Diagram for 61 Cases

Complete Linkage

Euclidean distances

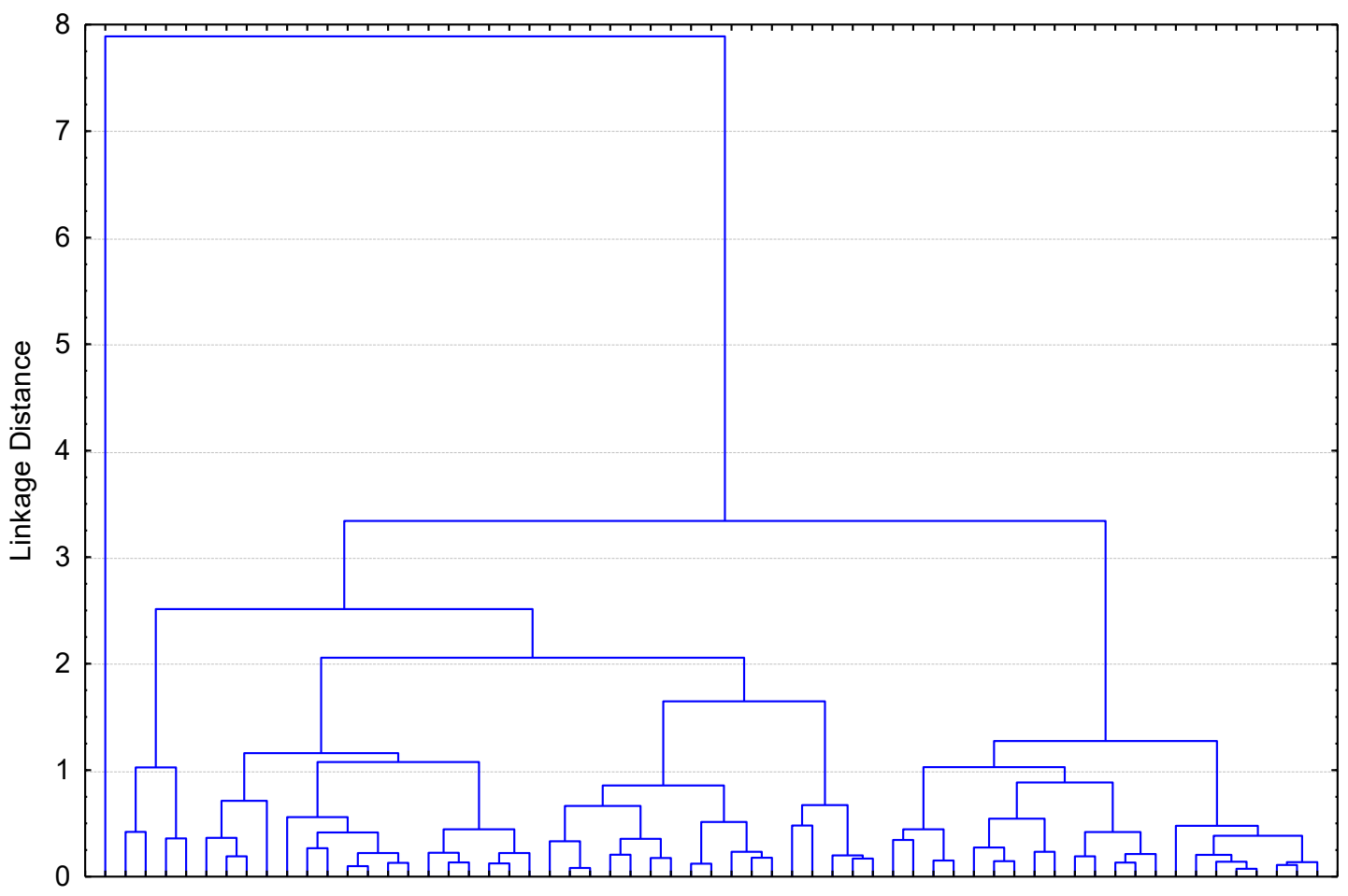

Figure 1. Distribution of countries by groups 
developing a better awareness of the processes related to the digital economy along with the deeper understanding of the digital economy input into country performance.

Indicator values have been standardized for analysis. First of all, it is necessary to find out if the indicators make clusters. For this, complete link method is used, and the Euclidean distance is proposed as a measure of proximity. The panel sample includes indicators of 61 countries for which there is comparable data for 2018 (World Digital
Competitiveness (WDC) ranking includes 63 countries, 61 of them are presented in Human Capital Index). The results of the analysis are given in Figure 1.

Based on the visual presentation of the results, it can be assumed that the indicators form four natural clusters (only one country is represented in one of the clusters (No. 4) - the USA). Table 1 shows the normalized values of the analyzed indicators by countries, the values of the Euclidean distance and the cluster number.

Table 1. Methods and data for the analyzed countries

\begin{tabular}{|c|c|c|c|c|c|}
\hline Country & ITR. current USD & $\mathrm{HCl}$ & WDC & CLUSTER & DISTANC \\
\hline Bulgaria & $5,072,000,000$ & 0.670277 & 43 & 1 & 0.36 \\
\hline Chile & $3,972,000,000$ & 0.665265 & 37 & 1 & 0.39 \\
\hline China & $40,386,000,000$ & 0.647099 & 30 & 1 & 0.48 \\
\hline Croatia & $12,075,000,000$ & 0.729366 & 44 & 1 & 0.34 \\
\hline Cyprus & $3,449,000,000$ & 0.754617 & 54 & 1 & 0.69 \\
\hline Greece & $21,594,000,000$ & 0.694806 & 53 & 1 & 0.41 \\
\hline Hungary & $9,595,000,000$ & 0.705065 & 46 & 1 & 0.33 \\
\hline Italy & $51,602,000,000$ & 0.75288 & 41 & 1 & 0.57 \\
\hline Malaysia & $21,774,000,000$ & 0.632579 & 27 & 1 & 0.54 \\
\hline Qatar & $15,239,000,000$ & 0.634826 & 28 & 1 & 0.53 \\
\hline Russian Federation & $18,670,000,000$ & 0.72895 & 40 & 1 & 0.26 \\
\hline Slovak Republic & $3,318,000,000$ & 0.68005 & 50 & 1 & 0.48 \\
\hline Spain & $81,250,000,000$ & 0.736156 & 31 & 1 & 0.99 \\
\hline Thailand & $65,242,000,000$ & 0.616861 & 39 & 1 & 0.78 \\
\hline Belgium & $10,381,000,000$ & 0.76276 & 23 & 2 & 0.18 \\
\hline Czech Republic & $8,291,000,000$ & 0.764517 & 33 & 2 & 0.18 \\
\hline Estonia & $2,332,000,000$ & 0.774125 & 25 & 2 & 0.2 \\
\hline Iceland & $3,128,000,000$ & 0.743431 & 21 & 2 & 0.25 \\
\hline Kazakhstan & $2,651,000,000$ & 0.77706 & 38 & 2 & 0.36 \\
\hline Latvia & $1,057,000,000$ & 0.738353 & 35 & 2 & 0.26 \\
\hline Lithuania & $1,419,000,000$ & 0.726695 & 29 & 2 & 0.19 \\
\hline Luxembourg & $5,537,000,000$ & 0.692369 & 24 & 2 & 0.38 \\
\hline New Zealand & $10,961,000,000$ & 0.771214 & 19 & 2 & 0.32 \\
\hline Poland & $15,748,000,000$ & 0.760222 & 36 & 2 & 0.28 \\
\hline Portugal & $24,105,000,000$ & 0.78344 & 32 & 2 & 0.34 \\
\hline Slovenia & $3,378,000,000$ & 0.788688 & 34 & 2 & 0.31 \\
\hline United Arab Emirates & $21,390,000,000$ & 0.676001 & 17 & 2 & 0.61 \\
\hline Argentina & $5,999,000,000$ & 0.617367 & 55 & 3 & 0.3 \\
\hline Brazil & $6,324,000,000$ & 0.545724 & 57 & 3 & 0.21 \\
\hline Colombia & $6,617,000,000$ & 0.598654 & 59 & 3 & 0.26 \\
\hline India & $29,143,000,000$ & 0.484796 & 48 & 3 & 0.61 \\
\hline Indonesia & $1,560,000,000$ & 0.537957 & 62 & 3 & 0.34 \\
\hline Jordan & $6,221,000,000$ & 0.54693 & 45 & 3 & 0.32 \\
\hline Mexico & $23,802,000,000$ & 0.611657 & 51 & 3 & 0.32 \\
\hline Mongolia & $526,000,000$ & 0.617309 & 61 & 3 & 0.41 \\
\hline Peru & $4,894,000,000$ & 0.594615 & 60 & 3 & 0.28 \\
\hline Philippines & $9,730,000,000$ & 0.549016 & 56 & 3 & 0.16 \\
\hline Romania & $3,261,000,000$ & 0.59441 & 47 & 3 & 0.28 \\
\hline Saudi Arabia & $16,975,000,000$ & 0.580753 & 42 & 3 & 0.38 \\
\hline South Africa & $9,789,000,000$ & 0.422549 & 49 & 3 & 0.9 \\
\hline
\end{tabular}


Table 1 (cont.). Methods and data for the analyzed countries

\begin{tabular}{|c|c|c|c|c|c|}
\hline Country & ITR. current USD & $\mathrm{HCl}$ & WDC & CLUSTER & DISTANC \\
\hline Turkey & $37,140,000,000$ & 0.62531 & 52 & 3 & 0.52 \\
\hline Ukraine & $2,269,000,000$ & 0.642379 & 58 & 3 & 0.47 \\
\hline United States & $2.56145 E+11$ & 0.713683 & 1 & 4 & 0 \\
\hline Australia & $47,327,000,000$ & 0.780834 & 13 & 5 & 0.32 \\
\hline Austria & $25,411,000,000$ & 0.768673 & 15 & 5 & 0.21 \\
\hline Canada & $21,978,000,000$ & 0.80009 & 8 & 5 & 0.15 \\
\hline Denmark & $9,097,000,000$ & 0.770832 & 4 & 5 & 0.42 \\
\hline Finland & $5,663,000,000$ & 0.814484 & 7 & 5 & 0.41 \\
\hline France & $73,125,000,000$ & 0.75596 & 26 & 5 & 0.89 \\
\hline Germany & $60,260,000,000$ & 0.763773 & 18 & 5 & 0.59 \\
\hline Hong Kong SAR. China & $4,1870,000,000$ & 0.821718 & 11 & 5 & 0.27 \\
\hline Ireland & $14,658,000,000$ & 0.813675 & 20 & 5 & 0.37 \\
\hline Israel & $8,073,000,000$ & 0.763064 & 12 & 5 & 0.38 \\
\hline Japan & $45,276,000,000$ & 0.840709 & 22 & 5 & 0.51 \\
\hline Korea. Rep. & $19,856,000,000$ & 0.834545 & 14 & 5 & 0.28 \\
\hline Netherlands & $2,5850,000,000$ & 0.803039 & 9 & 5 & 0.1 \\
\hline Norway & $7,096,000,000$ & 0.768535 & 6 & 5 & 0.42 \\
\hline Singapore & $20,416,000,000$ & 0.887084 & 2 & 5 & 0.63 \\
\hline Sweden & $14,926,000,000$ & 0.80251 & 3 & 5 & 0.35 \\
\hline Switzerland & $20,276,000,000$ & 0.766108 & 5 & 5 & 0.3 \\
\hline United Kingdom & $48,515,000,000$ & 0.776982 & 10 & 5 & 0.35 \\
\hline
\end{tabular}

Table 2. Analysis of variance

\begin{tabular}{l|c|c|c|c|c|c}
\hline \multicolumn{1}{c}{ Variable } & Between SS & df & Within SS & df & F & Signif. $p$ \\
\hline ITR & 46.66869 & 4 & 13.33131 & 56 & 49.00958 & 0.000000 \\
\hdashline $\mathrm{HCl}$ & 48.07283 & 4 & 11.92717 & 56 & 56.42746 & 0.000000 \\
\hdashline WDC & 50.94994 & 4 & 9.05006 & 56 & 78.81702 & 0.000000 \\
\hline
\end{tabular}

\section{RESULTS}

Verification of the assumption that the data form five clusters was carried out using the $\mathrm{K}$ means method. The results of the analysis of variance by clusters are presented in Table 2.

It is clear from Table 2 that the value of $p<0.05$ indicates a significant difference. The next step is to calculate the basic descriptive statistics for each cluster (Figure 2).

Tables 3-7 provide descriptive statistics for each of the cluster indicators.

Table 3. Descriptive statistics for Cluster 1 (the cluster contains 14 cases)

\begin{tabular}{l|c:c:c}
\hline Variable & Mean & Standard Deviation & Variance \\
\hline ITR & 0.060309 & 0.697325 & 0.486262 \\
\hdashline HCI & -0.166657 & 0.482048 & 0.232370 \\
\hdashline WDC & 0.467953 & 0.492430 & 0.242487 \\
\hline
\end{tabular}

Table 4. Descriptive statistics for Cluster 2 (the cluster contains 13 cases)

\begin{tabular}{c|c:c:c}
\hline Variable & Mean & Standard deviation & Variance \\
\hline ITR & -0.408439 & 0.215911 & 0.046618 \\
\hline HCI & 0.469704 & 0.358173 & 0.128288 \\
\hdashline WDC & -0.199139 & 0.388400 & 0.150855 \\
\hdashline
\end{tabular}

Table 5. Descriptive statistics for Cluster 3 (the cluster contains 15 cases)

\begin{tabular}{l|c:c:c}
\hline Variable & Mean & Standard deviation & Variance \\
\hline ITR & -0.31337 & 0.299016 & 0.089411 \\
HCI & -1.38699 & 0.607421 & 0.368961 \\
\hline WDC & 1.20097 & 0.345973 & 0.119698 \\
\hline
\end{tabular}

Table 6. Descriptive statistics for Cluster 4 (the cluster contains 1 case)

\begin{tabular}{c|c:c:c}
\hline Variable & Mean & Standard deviation & Variance \\
\hline ITR & 6.52602 & 0.00 & 0.00 \\
\hline $\mathrm{HCl}$ & 0.08675 & 0.00 & 0.00 \\
$\mathrm{WDC}$ & -1.70108 & 0.00 & 0.00 \\
\hline
\end{tabular}




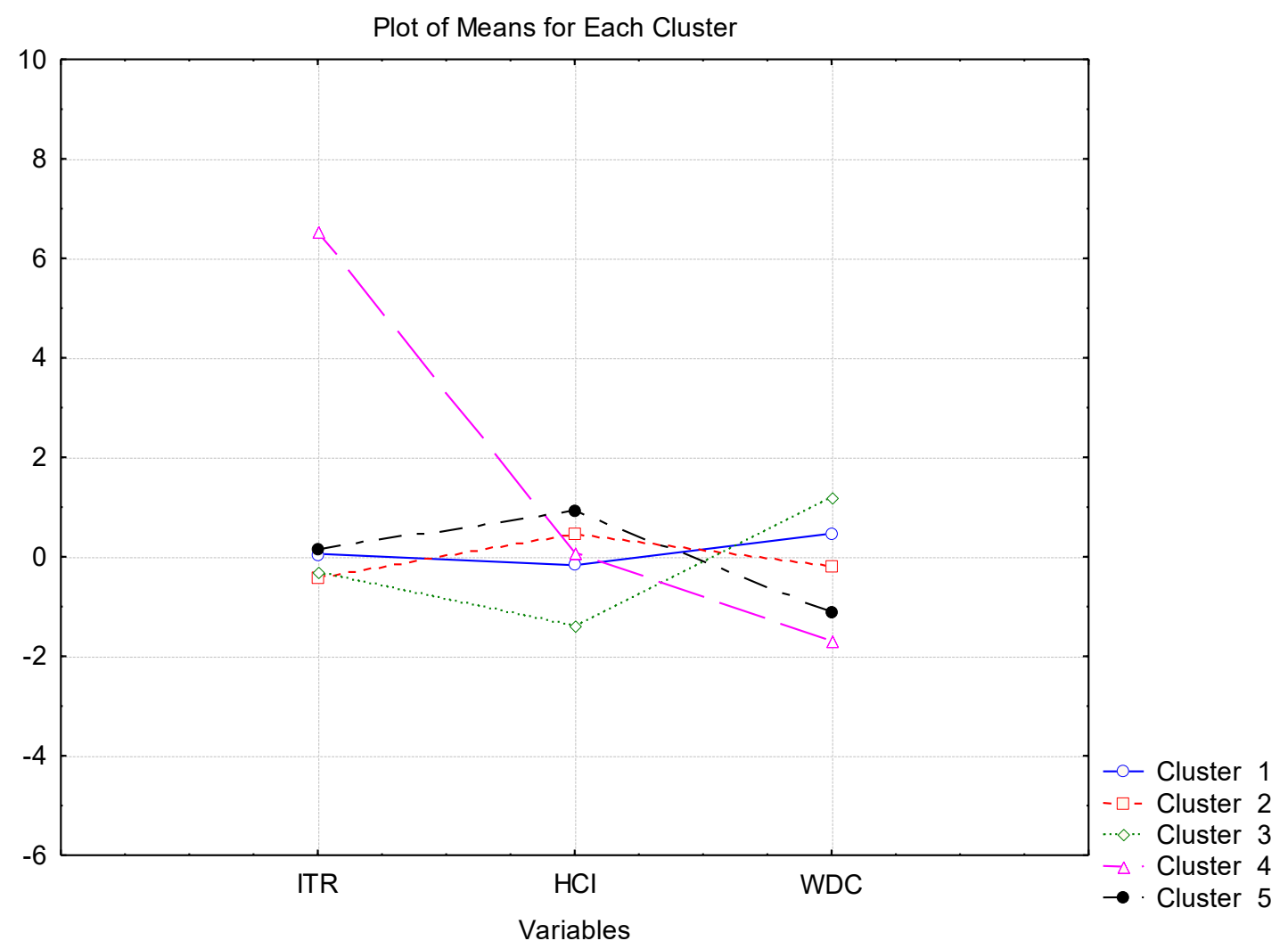

Figure 2. Values of indicators in clusters

Table 7. Descriptive statistics for Cluster 5 (the cluster contains 18 cases)

\begin{tabular}{c|c|c:c}
\hline Variable & Mean & Standard deviation & Variance \\
\hline ITR & 0.14666 & 0.552999 & 0.305808 \\
\hdashline HCI & 0.94140 & 0.359858 & 0.129497 \\
\hdashline WDC & -1.12645 & 0.376650 & 0.141865 \\
\hline
\end{tabular}

The following step is to plot the mean and confidence intervals for the variables in each cluster (Figure 3).

Thus, as follows from the analysis, the countries form four clusters, and in this case, the United States can be considered as an outlier due to the value of the International tourism receipts indicator, which is much higher than in other countries of the analyzed sample.

So, according to the research, the following clusters can be identified: Cluster 1: countries with average HCI and WDC values, depending on tourism. Cluster 2: countries with slightly above average $\mathrm{HCI}$ and WDC values that are less dependent on tourism. Cluster 3: countries with HCI and WDC values below average, not particularly de- pendent on tourism. Cluster 4: outliers. Cluster 5: countries with above average HCI and WDC that are tourism dependent.

The distribution of countries by clusters allows identifying certain patterns in each of them and can be used in the SWOT analysis of human resources and, on its basis, in the development of human capital strategies at tourism enterprises. An example of an SWOT analysis matrix of human resources and human capital strategies in tourism enterprises for Ukraine is shown in Table 8.

The transformations that technology brings are inevitable. And they, first of all, are reflected in human capital. The traditional ways of managing personnel in the tourism industry are changing significantly in the context of Economy 4.0. The ongoing processes are twofold, that is, on the one hand, the quality of working activity is improving, it becomes more creative and diverse, on the other hand, modern technological processes require highly qualified employees in the field of digital and information technologies, and at the same time lead to a decrease in the labor mar- 


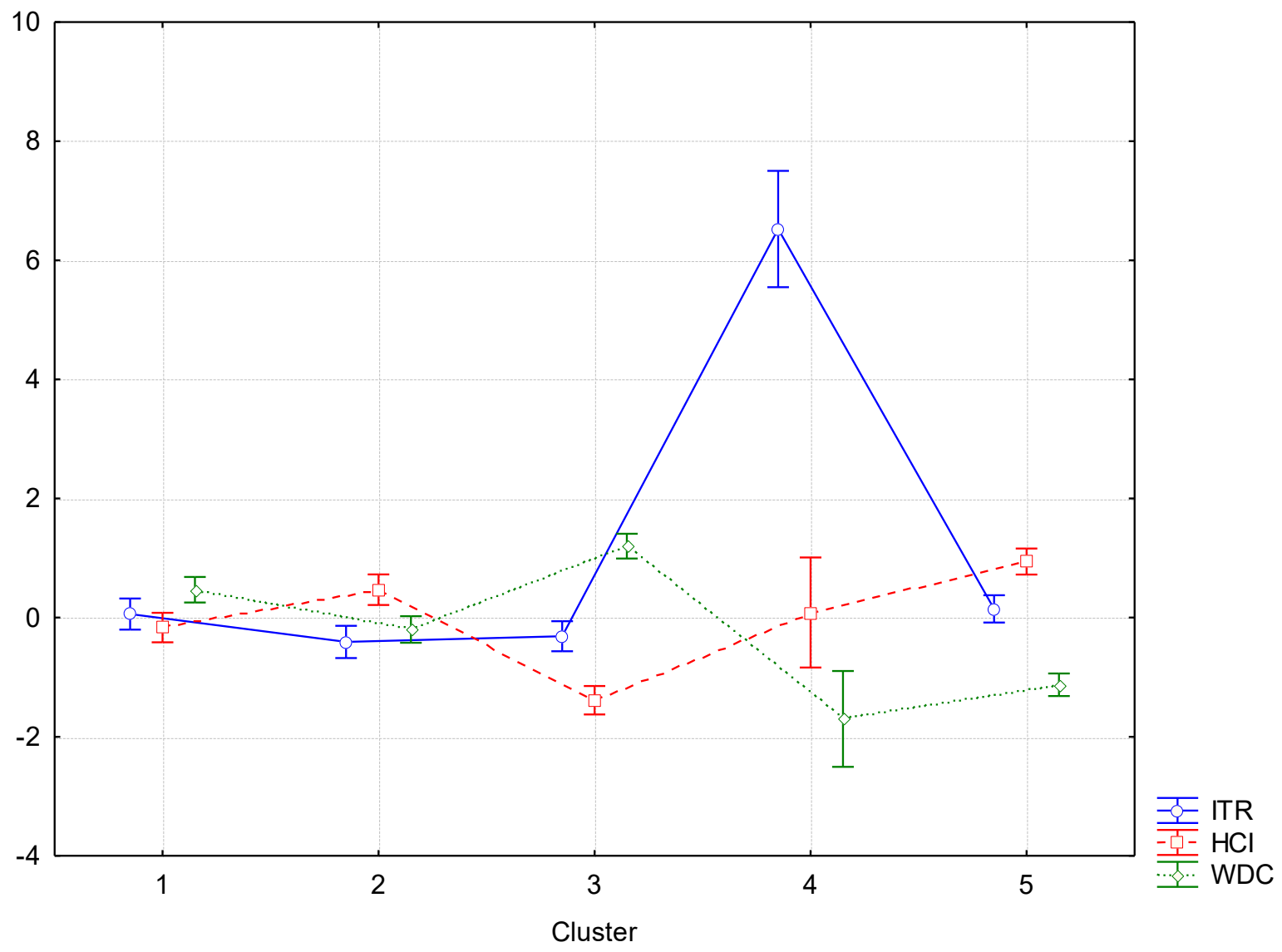

Figure 3. Mean and confidence intervals of variables in clusters

Table 8. SWOT analysis matrix of human resources and human capital strategies in tourism

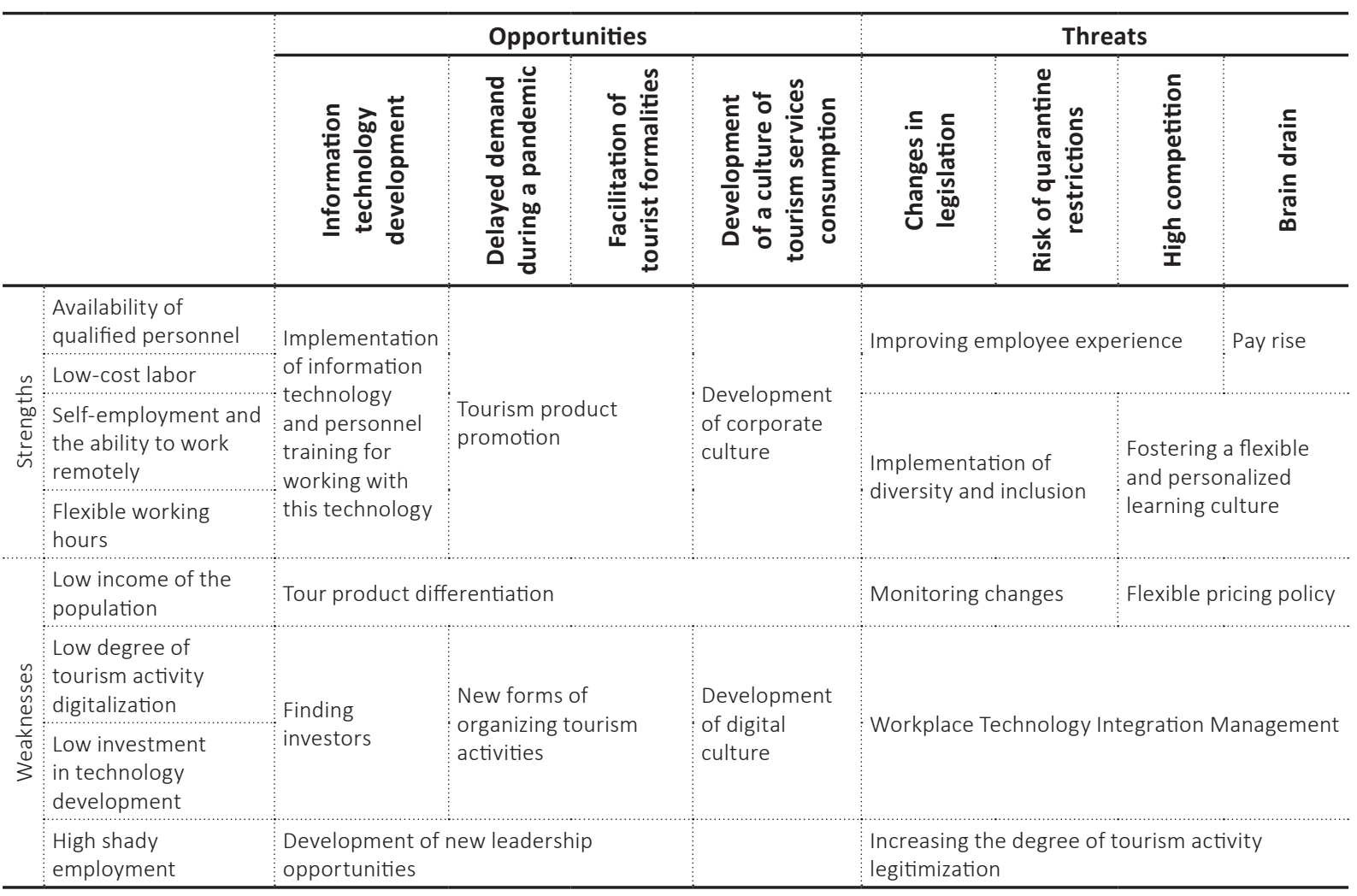


ket employment. In such conditions, it is necessary to optimally combine human resources and automation.

\section{DISCUSSION}

It must be recognized that the predominantly seasonal nature of the tourism industry accounts for a large share of the temporary and part-time personnel. The use of flexible forms of employment in tourism allows attracting large segments of the population to this area. However, employees who work part-time or temporarily during the season do not consider such work as long-term and are not motivated to invest in the development of the professional industry skills. Therefore, when developing human capital strategies in the tourism industry, it is necessary to account for the sectoral specifics of employment.

In addition, digital transformation has influenced not only industrial relations, hiring pol- icies, professional training of specialists, but also changed the approach to human resource management. The increase in the variety and complexity of the work performed by company employees cause certain changes in the labor market. The factors such as new technologies, on-the-job learning, soft skills, IoT, etc. facilitate the development of human capital in several directions, namely: (1) decreasing the number of jobs performed by humans; (2) distribute a labor force to other areas that produce higher added value; (3) expanding the demand for a labor force with skills and capabilities important for working with new technologies. The pace and depth of changes in the tourism sector, and the use of new technologies require a change in the way the personnel work, acquiring appropriate skills and qualifications. Due to this, the importance of creating a corporate education culture increases throughout the entire period of labor activity. In this regard, the issues of digitalization in the context of corporate culture also require further study and development.

\section{CONCLUSION}

Tourism is one of the industries most affected by digitalization. However, as has been determined in this paper, the degree of such influence is different for different countries and regions. As a result of the analysis carried out using the applied package Statistica, it was concluded that the impact of the digitalization level differs for groups of countries depending on the level of HCI and WDC, and is also determined by the dependence of the economy on tourism.

To determine the degree of influence of the economy digitalization level on human capital in the tourism industry, four groups of countries depending on the values of HCI and WDC have been identified. The analysis demonstrates that the degree of a country's dependence on tourism, as well as the value of HCI and WDC, determine its position in the cluster. In addition, a study using descriptive statistics showed that there were significant differences between the clusters. The results have confirmed the research hypothesis that the degree of the digital technology influence on the economy and society is heterogeneous. In the process of scientific research, it was found that the impact of Economy 4.0 varies across countries, depending on the level of human capital development and the degree of digitalization.

The identified distinctive features allow taking into account the peculiarities of each group of countries to develop human capital strategies in the tourism industry. As a practical implementation of the approach proposed in the paper, the Matrix of the SWOT analysis of human resources in tourism for Ukraine has been developed. It is proposed to single out main directions of human resource strategies in tourism using SWOT analysis. The peculiarity of the offered approach is that Opportunities, Threats, Strengths and Weaknesses are defined according to the characteristics of a cluster and can be used for the entire group of countries.

The results also show that in the modern conditions of the formation of Industry 4.0, digital technologies significantly affect the functioning of the tourism industry. At the same time, the digitalization of 
economic relations also influences human capital. This influence will increase with the development of society, moreover, unevenly across countries and sectors of the economy. Therefore, it is important for tourism organizations to develop human capital strategies accounting for Industry 4.0 trends and the peculiarities of their manifestation in a particular country.

\section{AUTHOR CONTRIBUTIONS}

Conceptualization: Olena Stryzhak.

Data curation: Olena Stryzhak, Olena Akhmedova.

Formal analysis: Olena Stryzhak.

Funding acquisition: Nelli Leonenko, Inna Lopatchenko, Nataliia Hrabar.

Investigation: Olena Stryzhak, Olena Akhmedova, Nelli Leonenko, Inna Lopatchenko, Nataliia Hrabar.

Methodology: Olena Stryzhak.

Project administration: Olena Stryzhak, Olena Akhmedova.

Resources: Olena Akhmedova, Nelli Leonenko, Inna Lopatchenko, Nataliia Hrabar.

Software: Olena Stryzhak.

Supervision: Olena Stryzhak.

Validation: Olena Akhmedova, Nelli Leonenko, Inna Lopatchenko, Nataliia Hrabar.

Visualization: Olena Stryzhak.

Writing - original draft: Olena Stryzhak.

Writing - review \& editing: Olena Akhmedova.

\section{REFERENCES}

1. Alamu, A. P. (2016). Human Capital Development Strategies for the Tourism, Hospitality, and Leisure Industry. Walden University. Walden Dissertations and Doctoral Studies Collections. Retrieved from https://core.ac.uk/ download/pdf/147835657.pdf

2. Betchoo, N. K. (2016). Digital transformation and its impact on human resource management: A case analysis of two unrelated businesses in the Mauritian public service. International Journal of Novel Research in Interdisciplinary Studies, 3(5), 1-10. https://doi.org/10.1109/EmergiTech.2016.7737328

3. Bourouaha, A., Sara, B., \& Maliki, S. B-E. (2017). Human capital for Tourism industry: Evidence from Algeria. Retrieved from https:// www.researchgate.net/publication/334283086

4. Costa, V., Moura, A., Mira, M. R., Cerdeiras, A., Cruz, I., Pereira, J., Martins, I. S., Conceição, O., Vilaça, A., Almeida, C., \& Carrança, P. (2019). HC Tourism. Profile and Trends of Human Capital in the Tourism Sector.
European Journal of Tourism, Hospitality and Recreation, 9(2), 40-51. https://doi.org/10.2478/ ejthr-2019-0009

5. Esu, B. B. (2012). Linking Human Capital Management with Tourism Development and Management for Economic Survival: The Nigeria Experience. International Journal of Business and Social Science, 3(11), 276-287. Retrieved from http://www.ijbssnet.com/journals/Vol_3_No_11_ June_2012/29.pdf

6. Flores, E., Xu, X., \& Lu, Y. (2020). Human Capital 4.0: a workforce competence typology for Industry 4.0. Journal of Manufacturing Technology Management, 31(4), 687-703. https://doi.org/10.1108/ JMTM-08-2019-0309

7. Frey, C. B., \& Osborne, M. (2017). The future of employment: How susceptible are jobs to computerisation? Technological Forecasting and Social Change, 114, 254-280. https://doi.org/10.1016/j. techfore.2016.08.019

8. Gadzhiev, N., Konovalenko, S., Trofimov, M., Leontieva,
J., \& Akhmedova, K. (2020). Management mechanism of human capital formation under a postindustrial economy. E3S Web of Conferences, 164 (Topical Problems of Green Architecture, Civil and Environmental Engineering 2019 (TPACEE 2019)). https://doi.org/10.1051/ e3sconf/202016410005

9. Gerasimova, N., Kulik, A., Zuppelo, A., \& Solovjev, D. (2020). Peculiarities of Intellectual Development of Human Capital at the Regional Level in the Context of Digital Transformation. Proceedings of the 8th International Conference on Contemporary Problems in the Development of Economic, Financial and Credit Systems (DEFCS 2020). Ser. Advances in Economics, Business and Management Research, vol. 157. https://doi.org/10.2991/ aebmr.k.201215.033

10. Hojeghan, S. B., \& Esfangareh, A. N. (2011). Digital economy and tourism impacts, influences and challenges. Procedia Social and Behavioral Science, 19, 308-316. 
https://doi.org/10.1016/j.sbspro.2011.05.136

11. IMD World Competitiveness Center. (n.d.). The World Digital Competitiveness ranking. Retrieved from https://www.imd.org/wcc/ world-competitiveness-centerrankings/world-digital-competitiveness-rankings-2020/

12. Kozmenko, O., Poluliakhova, O., \& Iastremska, O. (2015). Analysis of countries' investment attractiveness in the field of tourism industry. Investment Management and Financial Innovations, 12(3), 56-63. Retrieved from https://www. businessperspectives.org/journals/ investment-management-andfinancial-innovations/issue-100/ analysis-of-countries-investmentattractiveness-in-the-field-oftourism-industry

13. Lei, Z., \& Jing, Y. (2016). Study on Human Resource Reform in the Digital Transformation. Joint International Information Technology, Mechanical and Electronic Engineering Conference (JIMEC 2016). https://doi.org/10.2991/ jimec-16.2016.84

14. Lut, D. M., \& Vlad, F. (2017). The Role of Human Capital Development In Increase Competitiveness In Romanian Tourism Enterprises. Quaestus Multidisciplinary Research Journal, 19-28. Retrieved from https://www.quaestus.ro/en/ wp-content/uploads/2012/02/lut. dina2_.pdf

15. Pelinescu, E. (2015). The impact of human capital on economic growth. Procedia Econom$i c s$ and Finance, 22, 184-190. https://doi.org/10.1016/S22125671(15)00258-0

16. Rahim, A., Atan R., \& Kamaluddin, A. (2017). Human capital efficiency and firm performance: an empirical study on Malaysian technology industry. The 2016 $4^{\text {th }}$ International Conference on Governance and Accountability (2016 ICGA). https://doi. org/10.1051/shsconf/20173600026

17. Ribeiro, L. M. R. P., Gonçalves, E. C. C. Guerra, R. J. da C. (2020). The importance of qualification of the human resources in tourism: a study applied to travel agents in Portugal. Revista de Turismo y Patrimonio Cultural, 18(4), 667682. https://doi.org/10.25145/j. pasos.2020.18.047

18. Saraiva, C. C. O. (2018). Digital transformation and human capital: the resistance to change in the use of Information Systems. Retrieved from https://fenix.tecnico. ulisboa.pt/cursos/mise/dissertacao/846778572212093

19. Scavarda, A., Daú G., Scavarda, L. F., \& Caiado, R. G. G. (2019). An Analysis of the Corporate Social Responsibility and the Industry 4.0 with Focus on the Youth Generation: A Sustainable Human Resource Management Framework. https://doi.org/10.3390/ su11185130

20. Sima, V., Gheorghe, I.G., Subic, J., \& Nancu, D. (2020). Influences of the Industry 4.0 Revolution on the Human Capital Development and Consumer Behavior: A Systematic Review. Sustainability, 12(10), 4035. https://doi.org/10.3390/ su12104035

21. Ślusarczyk, B. (2018). Industry 4.0 - are we ready? Polish Journal of Management Studies, 17(1), 232-248. https://doi.org/10.17512/ pjms.2018.17.1.19

22. Stachová, K., Papula, J., Stacho Z., \& Kohnová, L. (2019). External Partnerships in Employee Education and Development as the Key to Facing Industry 4.0 Challenges. https://doi.org/10.3390/ su11020345

23. Stryzhak, O. (2019). Institutional System of Human Development and Institutional Environment: Relationship Features. Fifteenth Scientific and Practical International Conference "International Transport Infrastructure, Industrial Centers and Corporate Logistics" (NTI-UkrSURT 2019). https://doi. org/10.1051/shsconf/20196706049

24. Stryzhak, O. (2020). The relationship between education, income, economic freedom and happiness. The International Conference on History, Theory and Methodology of Learning (ICHTML 2020). https://doi. org/10.1051/shsconf/20207503004
25. Tay, S. I., Lee, T. C., Hamid, N. Z. A., \& Ahmad, A. N. (2018) An overview of industry 4.0: Definition, components, and government initiatives. Journal of Advanced Research in Dynamical and Control Systems, 10, 13791387. Retrieved from https:// simbotix.com.au/wp-content/ uploads/2020/06/I4.0-Defintiions. pdf

26. The World Bank. (n.d.). Retrieved from https://databank.worldbank. org

27. Tran, N. P., \& Vo, D. H. (2020). Human capital efficiency and firm performance across sectors in an emerging market. Cogent Business \& Management, 7(1). https://doi.or g/10.1080/23311975.2020.1738832

28. Whysall, Z., Owtram, M., \& Brittain, S. (2019). The new talent management challenges of Industry 4.0. Journal of Management Development, 38, 118-129. https://doi.org/10.1108/JMD-062018-0181

29. Wyrwicka, M. K., \& Mrugalska, B. (2017). "Industry 4.0" - Towards Opportunities and Challanges of Implementation (pp. 382387). In Proceedings of the 24th International Conference on Production Research. Retrieved from https://pdfs.semanticscholar.org/4439/ae896a521f8ef9e15a56eac7e4954387b155.pdf

30. Zaborovskaia, O., Nadezhina, O., \& Avduevskaya, E. (2020). The Impact of Digitalization on the Formation of Human Capital at the Regional Level. Journal of Open Innovation: Technology, Market, and Complexity, 6(4), 1-24. Retrieved from https://ideas.repec. org/a/gam/joitmc/v6y2020i4p184d457717.html 